\title{
Highly Efficient Binuclear Ruthenium Catalyst for Water Oxidation
}

\author{
Anett C. Sander ${ }^{[a]}$, Somnath Maji ${ }^{[b]}$, Laia Francàs ${ }^{[b]}$, Torben Böhnisch ${ }^{[a]}$, Sebastian Dechert ${ }^{[a]}$, Antoni \\ Llobet, ${ }^{[b] *}$ Franc Meyer ${ }^{[\mathrm{a}] *}$
}

\begin{abstract}
Water splitting is one of the key steps in the conversion of sunlight into a usable renewable energy carrier such as dihydrogen or more complex chemical fuels. Developing rugged and highly efficient catalysts for the oxidative part of water splitting, the water oxidation reaction generating dioxygen, is a major challenge in the field. Herein we introduce a new, and rationally designed, pyrazolate-based diruthenium complex with the highest activity in water oxidation catalysis for binuclear systems reported to date. Single crystal X-ray diffraction showed favorable preorganization of the metal ions, well suited for binding two water molecules at a distance adequate for $\mathrm{O}-\mathrm{O}$ bond formation, and redox titrations as well as spectro-electrochemistry allowed for characterization of the system in several oxidation states. Low oxidation potentials reflect the trianionic character of the elaborate compartmental pyrazolate ligand furnished with peripheral carboxylate groups. Water oxidation has been mediated both with a chemical oxidant (CelV) - using manometry and a Clark electrode for monitoring the dioxygen production - and electrochemically, with impressive activities.
\end{abstract}

The world's energy consumption is predicted to increase from 2010 to 2040 by $56 \%{ }^{[1]}$ Diminishing fossil energy resources make new technologies a necessity to meet future energy demands. Thus, the exploitation of renewable energy sources is of prime interest in chemical research today. In nature, photosynthesis uses solar energy to split water, generating protons and reducing equivalents for the production of organic material. Its artificial emulation is expected to yield energy rich organic material and dihydrogen as future energy carriers. ${ }^{[2]}$ The oxidative half reaction of water splitting, viz. the generation of dioxygen, is usually considered a bottleneck in this endeavor, since it represents a thermodynamically and kinetically demanding $4 \mathrm{e}^{-} / 4 \mathrm{H}^{+}$process. ${ }^{[3]}$ Today the quest for efficient catalysts for water oxidation (WOCs) remains to be one of the major research challenges in this field.

Binuclear ruthenium complexes have attracted much interest as WOCs, ${ }^{[4,5]}$ starting with T. J. Meyer's so-called Blue Dimer. ${ }^{[6]} \mathrm{A}$ significant advance was the use of a compartmental pyrazolate bridging ligand for preorganizing in close proximity the two metal ions in $\left[\{\operatorname{Ru}(\operatorname{trpy})\}_{2}(\mu \text {-Hbpp })(\mu \text {-OAc })\right]^{3+}$ (Figure 1, A $\left.(\mu \text {-OAc })^{2+}\right) \cdot{ }^{[7]}$ We recently reported a further elaboration of that motif by introducing a bis(terdentate) pyrazolate scaffold in $\left[\left\{\operatorname{Ru}(\text { py })_{2}\right\}_{2}(\mu \text {-Mebbp })(\mu-\mathrm{OAc})\right]^{2+}\left(\mathbf{B}(\mu-\mathrm{OAc})^{2+}\right)$ and its highly water soluble derivative $\left[\left\{\mathrm{Ru}\left(\mathrm{py}_{-} \mathrm{SO}_{3}\right)_{2}\right\}_{2}(\mu-\mathrm{Mebbp})\left(\mathrm{H}_{2} \mathrm{O}\right)_{2}\right]^{2+}\left(\mathbf{B}^{\prime}\left(\mathrm{H}_{2} \mathrm{O}\right)^{2-}\right)$, which is a rugged and quite efficient WOC. ${ }^{[8]}$ The related binuclear complex $\left[\left\{\mathrm{Ru}(\text { pic })_{2}\right\}_{2}(\mu \text {-dabpphtha })(\mathrm{Cl})\right]^{+} \quad\left(\mathrm{D}(\mu-\mathrm{Cl})^{+}\right)$ introduces two anionic carboxylic groups in its ligand structure, but at the same time forfeits the beneficial effect of the anionic pyrazolate bridge by using the neutral phthalazine unit instead. ${ }^{[9]}$ Despite these developments, however, the existing binuclear catalysts are still far from reaching nature's photosynthetic WOC efficiency. In 2012, the mononuclear ruthenium complexes $\left[\left\{\mathrm{Ru}(\mathrm{pic})_{2}\right\}(\mathrm{bpa})\right](\mathbf{C}(\mathbf{p i c}))$ and $\left[\left\{\mathrm{Ru}(\text { isoq })_{2}\right\}(\mathrm{bpa})\right]$ (C(isoq)) were reported to reach turn over frequencies (TOFs) of $32 \mathrm{sec}^{-1}$ and $303 \mathrm{sec}^{-1}$ under the conditions used in that work, ${ }^{[10]}$ which comes close to the performance of nature's oxygen evolving complex (OEC, TOF $\approx 300 \mathrm{sec}^{-1}$ ). ${ }^{[11]}$ Most recently, exceptionally fast WOCs with initial TOF's close to one thousand per second have been developed, namely cobalt complexes containing polyoxometalate ligands and related Ru-bpa complexes. ${ }^{[12,13]}$

The ligand system in $\mathbf{C}$ comprises two carboxylic groups that lower the oxidation potential of the ruthenium center. Since in the catalytic cycle a dimerization process has been proposed, ${ }^{[10,13,14]}$ we surmised that preorganizing two ruthenium ions in a pyrazolate-based binuclear complex with metal coordination environments akin to $\mathbf{C}$ and $\mathbf{D}(\mu-\mathbf{C l})^{+}$might give a catalyst with most favorable properties.

[a] A. C. Sander, T. Böhnisch, Dr. S. Dechert, Prof. Dr. F. Meyer Institute of Inorganic Chemistry, Georg-August-University Göttingen Tammannstraße 4, 37077 Göttingen (Germany)

franc.meyer@chemie.uni-goettingen.de www.meyer.chemie.uni-goettingen.de

[b] Dr. S. Maji, Dr. L. Francàs, Prof. Dr. A. Llobet Institute of Chemical Research of Catalonia (ICIQ) Av. Països Catalans 16, 43007 Tarragona (Spain) allobet@iciq.cat 

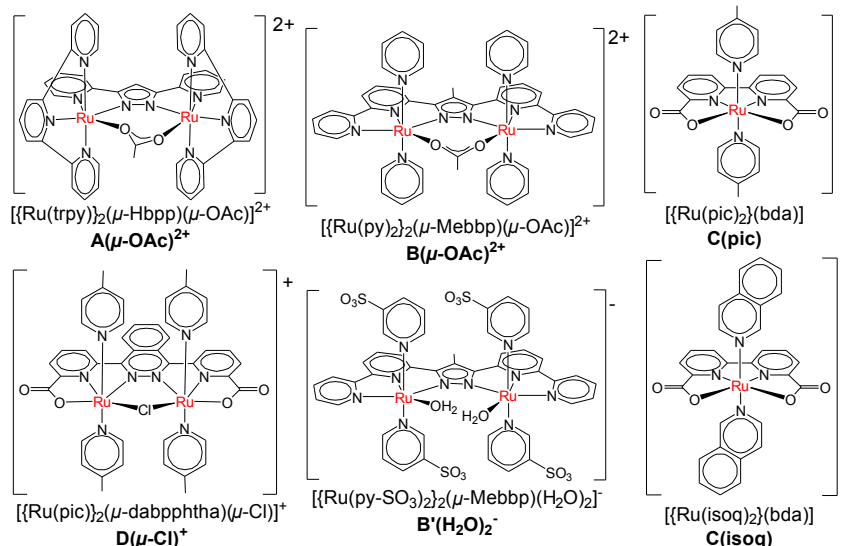

$\left[\left\{\mathrm{Ru}\left(\mathrm{py}-\mathrm{SO}_{3}\right)_{2}\right\}_{2}(\mu-\mathrm{Mebbp})\left(\mathrm{H}_{2} \mathrm{O}\right)_{2}\right]$

$B^{\prime}\left(\mathrm{H}_{2} \mathrm{O}\right)_{2}$

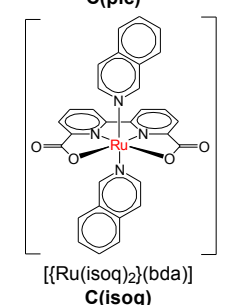

Figure 1. Ruthenium WOCs from literature discussed in this paper.

To this end we have now designed a new proligand $\mathbf{H}_{3} \mathrm{~L}$ (Scheme 1; see SI for ligand synthesis) that can be viewed as a hybrid of the ligands in $\mathbf{B}(\mu-\mathrm{OAC})^{2+}$ and $\mathbf{D}(\boldsymbol{\mu}-\mathrm{Cl})^{+} / \mathbf{C} . \mathrm{H}_{3} \mathrm{~L}$ provides, in its deprotonated form, two rigid and pyrazolate-bridged terdentate binding sites as well as pronounced anionic character because of the carboxylate and pyrazolate groups. $\mathrm{L}^{3-}$ positions two $\mathrm{Ru}$ ions in a well defined distance and enables them to simultaneously bind water molecules in close proximity within the bimetallic pocket, preset for O-O bond formation. As a future option, axial ligands may be easily varied, e.g. by using pyridines with different substituents, for tuning the electronic properties and the solubility of the catalyst.

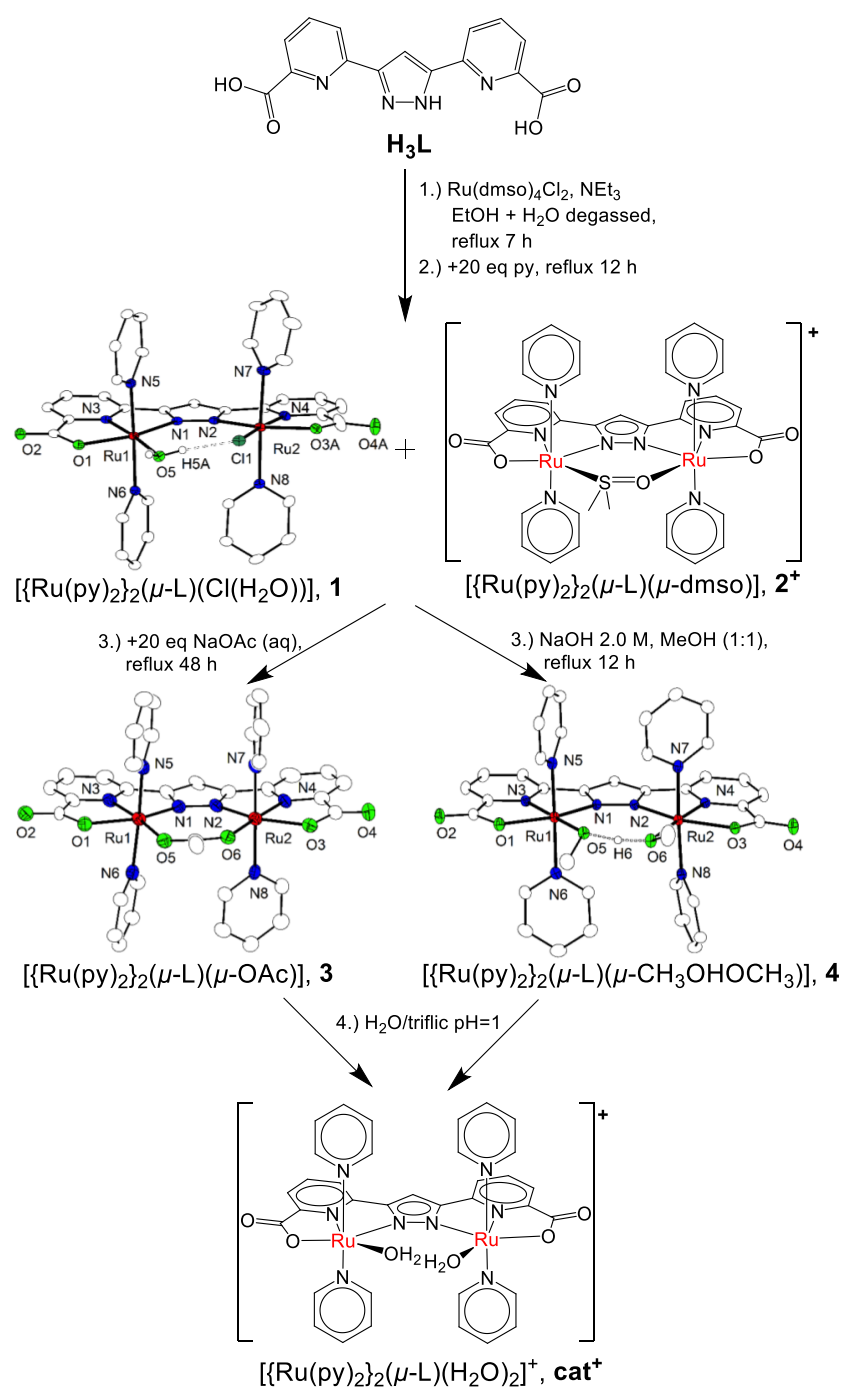

Scheme 1. Synthesis of the new WOC cat $^{+}$.

The synthesis of the new family of complexes $\left[\left\{R u(p y)_{2}\right\}_{2}(\mu-\right.$ $\mathrm{L})(\mathrm{X})$ ] (py is pyridine; $\mathrm{X}=\mathrm{H}_{2} \mathrm{O} / \mathrm{Cl}$ for $\mathbf{1}, \mathrm{X}=\mu$-dmso for $\mathbf{2}^{+}, \mathrm{X}=\mu$ OAc for $3, X=\mu-\mathrm{CH}_{3} \mathrm{OHOCH}_{3}$ for 4 and $\mathrm{X}=\left(\mathrm{H}_{2} \mathrm{O}\right)_{2}$ for cat $\left.{ }^{+}\right)$is depicted in Scheme 1. To avoid the formation of grid like complexes ${ }^{[15]}$ the ligand $H_{3} \mathrm{~L}$ has to be added in deprotonated form very slowly to a solution of $\mathrm{Ru}(\mathrm{dmso})_{4} \mathrm{Cl}_{2}$. The intermediate $\mu$-dmso- and $\mathrm{Cl} / \mathrm{H}_{2} \mathrm{O}$-bridged complexes, $\mathbf{1}$ and $\mathbf{2}^{+}$, were heated further at reflux in a degassed mixture of ethanol and water with an excess of $\mathrm{NaOAc}$ to yield the catalyst precursor complex 3 . Acetate-bridged 3 can be isolated from the reaction mixture after solvent evaporation by $\cdot$ taking advantage of the different solubility properties of the components. A different route is the synthesis of a methanol-methanolato bridged complex 4 via heating the intermediate complexes 1 or $2^{+}$in a mixture of $2 \mathrm{M}$ $\mathrm{NaOH}(\mathrm{aq}) /$ methanol $(1: 1)$ to reflux over night. The catalyst cat $^{+}$ is finally generated from its immediate precursors 3 and $\mathbf{4}$ in acidic aqueous solution $\left(\mathrm{H}_{2} \mathrm{O} / \mathrm{CF}_{3} \mathrm{SO}_{3} \mathrm{H}, \mathrm{pH}=1.0\right)$ via exchange of the bridging moiety. Replacement of the acetate bridge under 
acidic conditions has been evidenced by NMR studies and ESI mass spectrometry (see Figures S18 S19).

Characterization of the complexes in solution by NMR shows the diamagnetic character of the low spin $d^{6} R u^{\prime \prime}$ centres (see Figures S1-S13). In the case of intermediates 1 and $\mathbf{2}^{+}$the spectra reflect the reduced symmetry $\left(\mathrm{C}_{\mathrm{s}}\right)$ of the complexes, whereas the spectra of $\mathbf{3}$ and $\mathbf{4}$ both feature fewer resonances because of their apparent $C_{2 v}$ symmetry. Complexes 1, 3 and 4 were further characterised by X-ray diffraction (Scheme 1 and Supporting Information). Similar to the Mebbp- ligand in $\mathbf{B}(\boldsymbol{\mu}$ OAc) ${ }^{2+},{ }^{[8]} \mathbf{L}^{3-}$ spans the two $\mathrm{Ru}$ ions and serves as a bismeridional scaffold, and the monodentate pyridines occupy axial positions. From the crystallographically determined molecular structure of $\mathbf{4}$ one can anticipate how the catalyst looks like under neutral $\mathrm{pH}$ conditions; note that the $\left(\mathrm{H}_{3} \mathrm{C}\right) \mathrm{O}-\mathrm{H} \cdots \mathrm{O}\left(\mathrm{CH}_{3}\right)$ moiety in $\mathbf{4}$ is labile and is prone to undergo rapid methanol/water exchange, ${ }^{[16]}$ and that the resulting complex with $\mathrm{HO}-\mathrm{H} \cdots \mathrm{OH}$ bridge represents a singly deprotonated form of cat $^{+}{ }^{[17]}$ It is also noteworthy that all equatorial atoms originating from the $\mathrm{L}^{3-}$ and OAc- ligands in $\mathbf{3}$ are situated roughly within a plane, and hence the RuNNRu torsion angle along the pyrazolate unit in complex 3 is small $\left(3.6^{\circ}\right)$ which is similar to the situation in $\mathbf{B}(\mu-\mathbf{O A c})^{2+}\left(0.4^{\circ}\right) .^{[8]}$ In contrast, the acetate is strongly tilted and the RuNNRu torsion angle is much larger $\left(25.4^{\circ}\right)$ in the previously reported catalyst $\mathbf{A}(\mu-\mathbf{O A c})^{2+} \cdot{ }^{[7]}$ This is important because in the case of $\mathrm{B}(\mu-\mathrm{OAc})^{2+}$ the acetate is tightly bound and not readily hydrolyzed under acidic conditions. Exchange of the acetate bridge in cat $^{+}$is likely facilitated by the significantly lower charge of the $\left[\left\{R u(p y)_{2}\right\}_{2}(\mu \text {-L) }]^{+}\right.$scaffold compared to $\left[\left\{\operatorname{Ru}(\mathrm{py})_{2}\right\}_{2}(\mu-\mathrm{Mebbp})\right]^{3+}$. Hydrolysis of the acetate bridge in $\mathbf{3}$ is evident from NMR spectroscopy and also in electrochemical experiments, since both complexes 3 and 4 produce the same cyclic voltammogram (CV) in acidic aqueous solution $(0.1 \mathrm{~m}$ triflic acid), reflecting the exchange of their bridging units and the formation of cat $^{+}$under those conditions.

Redox properties of 3, 4, and cat $^{+}$were investigated by means of $\mathrm{CV}$ and square wave voltammetry (SQWV) ${ }^{[18]}$ Figure 2 (left) shows the CVs of 3 and 4 in DCM using $0.1 \mathrm{M} \mathrm{NBu}_{4} \mathrm{PF}_{6}$, as supporting electrolyte. In both cases the CV displays two chemically reversible waves that are assigned to two consecutive $1 e^{-}$steps associated with the $\mathrm{Ru}^{\prime \prime \prime} \mathrm{Ru}^{\prime \prime}+1 \mathrm{e}^{-} \rightarrow$ $\mathrm{Ru}^{\prime \prime} \mathrm{Ru} u^{\prime \prime}$ and the $\mathrm{Ru}^{\text {III }} \mathrm{Ru} \mathrm{u}^{\mathrm{III}}+1 \mathrm{e}^{-} \rightarrow \mathrm{Ru} \mathrm{u}^{\text {III }} \mathrm{Ru}$ " processes. UV-vis spectra of all species are reported in the Supporting Information, Figure S21.
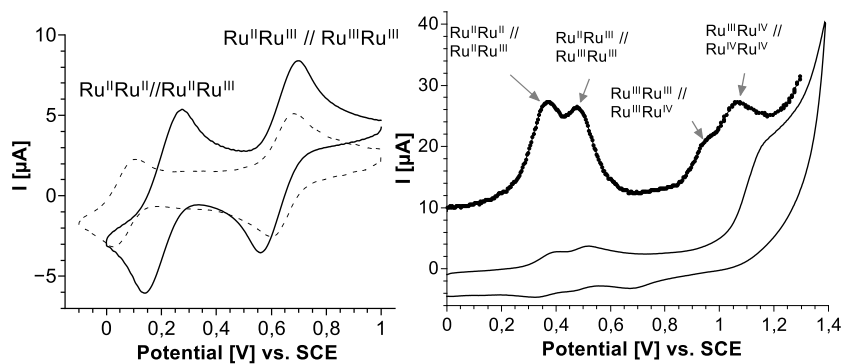

Figure 2. Left: $\mathrm{CVs}$ of 3 (bold line) and 4 (dashed line) in $\mathrm{DCM}, 0.1 \mathrm{M} \mathrm{NBu} \mathrm{PF}_{6}$ solution. Right: $\mathrm{CV}$ and $\mathrm{SQWV}$ of $\mathrm{cat}^{+}$in $\mathrm{H}_{2} \mathrm{O} / \mathrm{CF}_{3} \mathrm{SO}_{3} \mathrm{H}(0.1 \mathrm{M}, \mathrm{pH}=1.0)$ solution.
Redox potentials of the two sequential processes in organic solvent are compiled in Table 1 together with those of related mononuclear and dinuclear complexes for comparison. It is interesting to realize here that for dinculear complexes, the replacement of two pyridyl donors in $\mathbf{A}(\mu-\mathbf{O A c})^{2+}$ and $\mathbf{B}(\mu-$ $\mathrm{OAc}^{2+}$ by two anionic carboxylate groups in the ligand framework of 3 leads to a huge cathodic shift of around 400-500 $\mathrm{mV}$ (compare entries 4,5 and 7 in Table 1). The very low potentials of $\mathbf{3}$ and $\mathbf{4}$ thus reflect the beneficial effect of the rationally designed new trianionic binucleating ligand $\mathrm{L}^{3-}$.

Table 1. Redox potentials in organic solvents for complexes $\mathbf{3}$ and $\mathbf{4}$ and for related mononuclear and dinuclear complexes reported in the literature.

\begin{tabular}{|c|c|c|c|c|}
\hline \multirow[t]{2}{*}{ entry } & \multirow{2}{*}{ Complex } & \multicolumn{2}{|c|}{$E_{1 / 2}[\mathrm{~V}$ vs. SCE] } & \multirow{2}{*}{ Ref } \\
\hline & & III,II / II,II & III,III / III,II & \\
\hline 1 & $\{\mathrm{Ru}(\mathrm{trpy})(\mathrm{bpy})(\mathrm{Cl})\}^{a}$ & $0.86(\mathrm{III} / \mathrm{II})$ & -- & 19 \\
\hline 2 & $\mathrm{C}(\text { pic })_{2}{ }^{a}$ & $0.46(\mathrm{III} / \mathrm{II})$ & --- & $\begin{array}{l}\text { this work } \\
\text { (Fig. S20) }\end{array}$ \\
\hline 3 & $\mathrm{C}\left(\right.$ isoq $_{2}{ }^{a}$ & $0.41(\mathrm{III} / \mathrm{II})$ & -- & $\begin{array}{l}\text { this work } \\
\text { (Fig. S20) }\end{array}$ \\
\hline 4 & $\mathrm{~A}(\mu-\mathrm{OAc})^{2+a}$ & 0.72 & 1.04 & $5,7 a$ \\
\hline 5 & $\mathrm{~B}(\mu-\mathrm{OAc})^{2+b}$ & 0.64 & 1.04 & 8 \\
\hline 6 & $\mathrm{D}(\mu-\mathrm{Cl})^{+c}$ & 0.66 & 1.16 & 9 \\
\hline 7 & $3^{a}$ & 0.21 & 0.63 & this work \\
\hline 8 & $4^{a}$ & 0.06 & 0.64 & this work \\
\hline
\end{tabular}

${ }^{a} \mathrm{DCM}$ : dichloromethane, ${ }^{b}$ propylene carbonate, ${ }^{c} \mathrm{MeCN}$

The $\mathrm{CV}$ of cat $^{+}$in aqueous solution at $\mathrm{pH}=1.0(0.1 \mathrm{~m}$ triflic acid; Figure 2 right) shows two chemically reversible redox waves at 0.37 and $0.45 \mathrm{~V}$ that are tentatively assigned to two consecutive one electron oxidations giving $\mathrm{Ru}^{\text {II }} \mathrm{Ru}$ 'II and $\mathrm{Ru} \mathrm{u}^{\mathrm{III}} \mathrm{Ru}$ 'II species, respectively. Their one electron nature is corroborated by chemical redox titrations experiments at $\mathrm{pH}=1.0$ (see Figure 3 , and Figure $\mathrm{S} 22$ in the $\mathrm{SI}$ ). Redox titrations using $\left(\mathrm{NH}_{4}\right)_{2}\left[\mathrm{Ce}\left(\mathrm{NO}_{3}\right)_{6}\right]$ (abbreviated as Ce $\mathrm{IV}^{\mathrm{IV}}$ or $\mathrm{CAN} ; 0.1$ eq per $10 \mu \mathrm{L}$, $\mathrm{H}_{2} \mathrm{O} / \mathrm{CF}_{3} \mathrm{SO}_{3} \mathrm{H}, \mathrm{pH} 1,0.1 \mathrm{~m}$ ) furthermore provide the spectra of the individual species at oxidation states $\mathrm{Ru}^{\prime \prime} \mathrm{Ru}$ ", $\mathrm{Ru}^{\text {III }} \mathrm{Ru}$ " and $\mathrm{Ru}^{\mathrm{III}} \mathrm{Ru} \mathrm{u}^{\mathrm{III}}$. Further addition of $\mathrm{Ce}^{\mathrm{IV}}$ generates the $\mathrm{Ru}^{\mathrm{IV}} \mathrm{Ru}^{\mathrm{III}}$ species that is not stable for long periods of time under these conditions. 

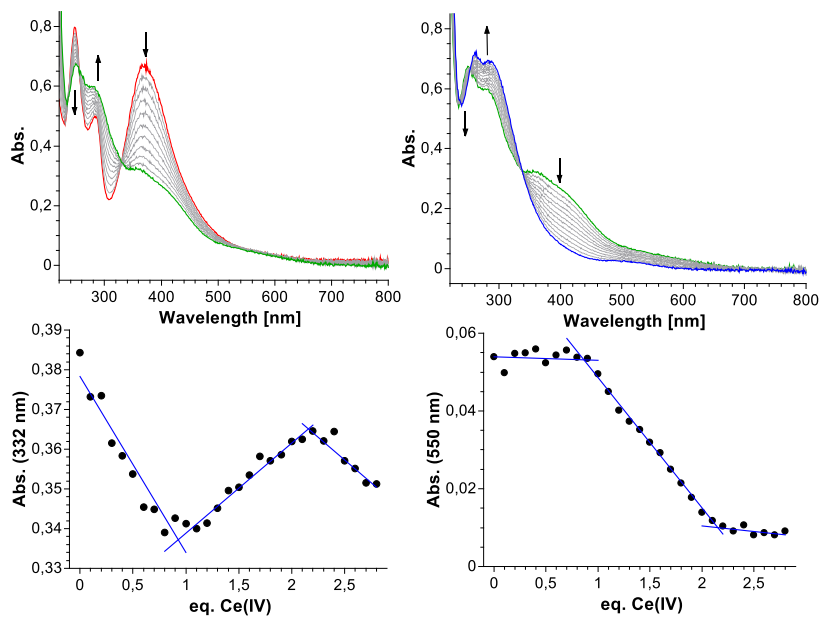

Figure 3. Redox titration in $\mathrm{H}_{2} \mathrm{O} / \mathrm{CF}_{3} \mathrm{SO}_{3} \mathrm{H}(\mathrm{pH}=1.0 ; 0.1 \mathrm{~m})$ of $^{\text {cat }^{+}}\left(5 \cdot 10^{-5} \mathrm{M}\right.$, $10 \mathrm{~mL}$ ) using $\mathrm{Ce}^{\mathrm{IV}}$ in $0.1 \mathrm{eq}$ steps $\left(5 \cdot 10^{-3} \mathrm{M}\right.$, in $10 \mu \mathrm{L}$ steps). Top: UV-vis spectra of first (left) and second (right) oxidation (red: [Ru"Ru $\left.{ }^{\prime \prime}\right]$, green: $\left[\mathrm{Ru}^{\text {III }} \mathrm{Ru}{ }^{\mathrm{II}}\right.$, blue: $\left[\mathrm{Ru}^{\mathrm{III}} \mathrm{Ru} \mathrm{u}^{\mathrm{III}}\right]$ ); bottom: absorption changes at selected wavelengths (332 $\mathrm{nm}$ and $550 \mathrm{~nm})$.

Besides the two one electron waves a catalytic peak current whose foot of the wave appears at $0.92 \mathrm{~V}$ is observed in the CV of cat $^{+}$(Figure 2 right); a DPV for cat $^{+}$under identical condition is also included in the right part of Figure 2. The DPV shows two peaks that coincide with the first two oxidations just described and two more peaks at 0.94 and $1.07 \mathrm{~V}$ that are assigned to two further consecutive one electron oxidations to generate the $\mathrm{Ru}^{\mathrm{III}} \mathrm{Ru} \mathrm{u}^{\mathrm{IV}}$ and $\mathrm{Ru}^{\mathrm{IV}} \mathrm{Ru} \mathrm{u}^{\mathrm{IV}}$ species, respectively. It is interesting to note here that the latter two redox processes are located just below the catalytic wave observed in the $\mathrm{CV}$, which suggests that the $\mathrm{Ru}^{\mathrm{IV}} \mathrm{Ru^{ \textrm {IV } }}$ species is responsible for water oxidation. We do not know the exact proton content of this species but it can

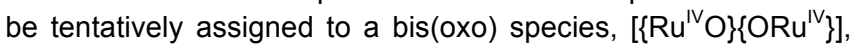
where $4 \mathrm{H}^{+}$and $4 \mathrm{e}^{-}$have been removed from the initial $\left[\left\{\mathrm{Ru}^{\prime \prime}\left(\mathrm{OH}_{2}\right)\right\}\left\{\left(\mathrm{H}_{2} \mathrm{O}\right) \mathrm{Ru}^{\prime \prime}\right\}\right]^{+}$complex, cat $^{+}$, in close analogy to what has been observed for the type $\mathbf{A}$ and $\mathbf{B}$ dinuclear complexes (compare Figure 1). ${ }^{[7,8]}$

In order to obtain kinetic information about the catalytic process, a foot of the wave analysis was carried out to calculate apparent rate constant $k_{\text {cat }}$. We followed the methodology described by Saveant et al. ${ }^{[20]}$ which assumes that the rate determining step (rds) is the last electron transfer step. Under catalytic conditions eq. (1) is operative,

$$
\frac{i_{c a t}}{i_{d}}=\frac{2.24 \sqrt{\frac{R T}{F v} C_{A}{ }^{0} k_{c a t}}}{1+\exp \left[\frac{F}{R T}\left(E_{c a t}^{0}-E\right)\right]}
$$

where $E_{\text {cat }}^{0}$ is the standard potential for the catalysis-initiating redox couple $(1.07 \mathrm{~V}), i_{\text {cat }}$ is the current intensity in the presence of substrate, $i_{d}$ is the current intensity in the absence of substrate (here we approximate this current to the current associated with the $\mathrm{Ru}^{\text {III }} \mathrm{Ru}$ "/Ru"Ru" couple), $F$ is the faraday constant, $v$ is the scan rate, $C^{\circ}{ }_{A}$ is the concentration of substrate $(55.56 \mathrm{M}$ for water) and $\mathrm{R}$ is $8.314 \mathrm{~J} \cdot \mathrm{mol}^{-1} \mathrm{~K}^{-1}$. Background corrected $\mathrm{CVs}$ of cat $^{+}$at different scan rates $\left(10-90 \mathrm{mV} \cdot \mathrm{s}^{-1}\right)$ are shown in Figure 4 (left). Now, $k_{\text {cat }}$ can be extracted from the plot of $i_{\text {cat }} / i_{\mathrm{d}} v s$. $1 /\left\{1+\exp \left[(\mathrm{F} / \mathrm{RT})\left(E_{\text {cat }}^{\circ} E\right)\right]\right\}$ as shown in Figure 4 (right) and in Figure S25 in the SI. The largest slope at the very beginning of the catalytic process gives an impressive value of $k_{\text {cat }}=7 \pm 4 \mathrm{~s}^{-1}$. It should be noted that kinetic parameters for catalytic reactions derived from electrochemical measurements depend on various details of the experimental procedures, and values from different studies should be compared only with caution. ${ }^{[21]}$
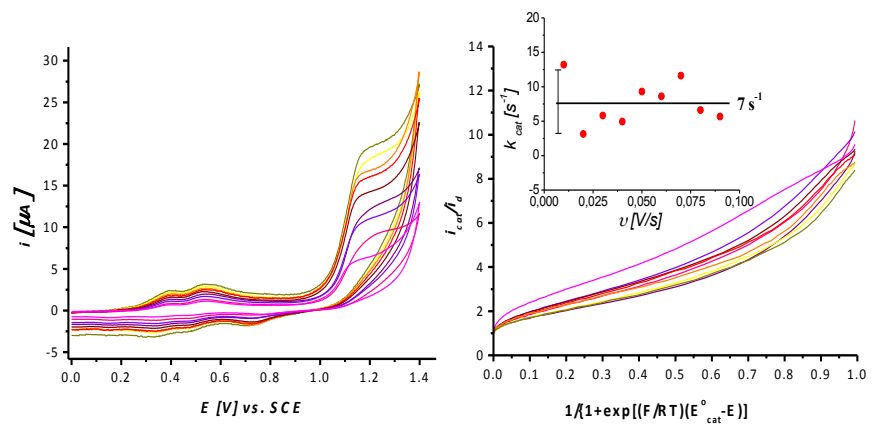

Figure 4. Left: Background corrected $\mathrm{CVs}$ in $\mathrm{H}_{2} \mathrm{O} / \mathrm{CF}_{3} \mathrm{SO}_{3} \mathrm{H}(\mathrm{pH}=1.0)$ at 10 $90 \mathrm{mV} \cdot \mathrm{s}^{-1}$ scan rates. Color codes: magenta, 10; pink, 20; violet, 30; purple, 40; wine, 50; red, 60; orange, 70; yellow, 80; brown, $90 \mathrm{mV} / \mathrm{s})$. Right: foot of the wave analysis plotting $i_{\text {cat }} / i_{d} v s .1 /\left\{1+\exp \left[(F / R T)\left(E_{c a}^{\circ}-E\right)\right]\right\}$ at each scan rate (same color code). Inset: plot of the different $k_{\text {cat }}$ values extracted from the foot of the wave analysis at each scan rate. The black line represents the average $k_{\text {cat }}$ value.

The catalytic performance of cat ${ }^{+}$was also studied chemically in $0.1 \mathrm{M}$ triflic acidic aqueous solutions using CAN as oxidant. Dioxygen production was simultaneously monitored by manometry and by a Clark electrode in the gas phase of the reaction vessel. The system cat $^{+} 0.1 \mathrm{mM} / \mathrm{Ce}^{\mathrm{IV}} 10 \mathrm{mM} / 0.1 \mathrm{M}$ aqueous triflic acid (total solution volume $2 \mathrm{~mL}$ ) gives $4.8 \mu \mathrm{mol}$ of $\mathrm{O}_{2}$ which corresponds to 24 turn overs (TN) with an impressive and nearly quantitative oxidative efficiency of $96 \%$, and with an initial turnover frequency $\left(\mathrm{TOF}_{\mathrm{i}}\right.$ ) of $1.4 \mathrm{~s}^{-1}$. A second addition of $\mathrm{Ce}^{\mathrm{IV}}$ to the same solution generates again $4.8 \mu \mathrm{mol}$ of $\mathrm{O}_{2}$ although the TOF $i$ now is slightly lower (Figure 5 left).
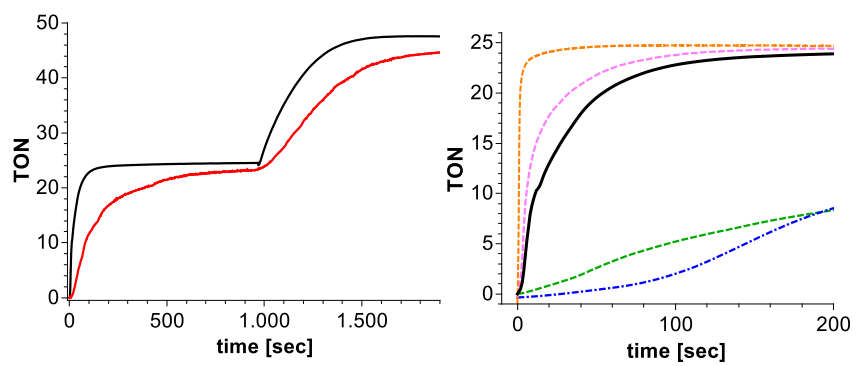

Figure 5. Water oxidation catalysis in $\mathrm{H}_{2} \mathrm{O} / \mathrm{CF}_{3} \mathrm{SO}_{3} \mathrm{H}$ solution $(0.1 \mathrm{~m}, \mathrm{pH}=1.0$, $\mathrm{V}=2 \mathrm{~mL}),\left[\mathbf{c a t}^{+}\right]=0.1 \mathrm{mmol} \cdot \mathrm{L}^{-1}$. Left: two times 100 eq. Ce ${ }^{\mathrm{IV}}$ monitored by manometry (black line) and oxygen sensor (red line; differences are due to the slow response time of the Clark electrode in the gas phase of the reaction 
vessel), right: manometry data for the first $200 \mathrm{~s}$ of catalysis (under identical conditions) of cat $^{+}$(black), $\mathbf{A}\left(\mathrm{H}_{2} \mathrm{O}\right)_{2}{ }^{3+}$ (blue), $\mathbf{B}^{\prime}\left(\mathrm{H}_{2} \mathrm{O}\right)_{2}{ }^{-}$(green), $\mathbf{C}$ (pic) (magenta) and $\mathbf{C}$ (isoq) (orange).

Consistency of the results with regard to the oxidative efficiency, obtained after the first and second addition of $\mathrm{Ce}^{\mathrm{IV}}$, indicates full integrity of the molecular catalyst, which was further corroborated by ESI mass spectrometry (see Figure S24). On the other hand the slight decrease of the $\mathrm{TOF}_{i}$ upon the second $\mathrm{Ce}^{\mathrm{IV}}$ addition is due to the increasing $\mathrm{NO}_{3}^{-}$concentration is solution, as was proven by repeating the same experiment with different amounts of $\mathrm{NO}_{3}{ }^{-}$added prior to the start of the catalytic reaction (see Figure $\mathrm{S} 23$ in the $\mathrm{SI}$ ). This phenomenon is associated with an anion binding equilibrium (anation; see eq. (2)) that has also been observed previously for other systems. ${ }^{[4]}$ The anation phenomenon might also be responsible for a somewhat lower $\mathrm{TOF}_{\mathrm{i}}$ in the CAN-mediated reaction compared to the electrochemically determined $k_{\text {cat }}$ (which here coincides with $\mathrm{TOF}_{\mathrm{i}}$ ).

$$
\underset{\text { cat }^{+}}{\left[\mathrm{Ru}-\mathrm{OH}_{2} \mathrm{H}_{2} \mathrm{O}-\mathrm{Ru}\right]}+\mathrm{NO}_{3}^{-} \rightleftharpoons \underset{\mathrm{O}}{\left[\mathrm{Ru}_{-}^{-}\right.} \mathrm{O}_{-\mathrm{N}^{-}}^{-\mathrm{Ru}]}+2 \mathrm{H}_{2} \mathrm{O}
$$

Thermodynamic and kinetic parameters for cat $^{+}$and related mononuclear and dinuclear Ru complexes are collected in Table 2. In order to allow useful comparison, the 1:100 cat $^{+}: \mathrm{Ce}^{\mathrm{IV}}$ reaction shown in Figure 5 (left) was repeated under exactly the same conditions for mononuclear $\mathbf{C}$ (pic) and $\mathbf{C}$ (isoq) as well as for dinuclear $\mathbf{A}\left(\mathrm{H}_{2} \mathrm{O}\right)_{2}{ }^{3+}$ and $\mathbf{B}^{\prime}\left(\mathrm{H}_{2} \mathrm{O}\right)_{2}{ }^{-}$complexes; manometry data for the first $200 \mathrm{~s}$ of catalysis are shown in Figure 5 (right), and the resulting TOF $_{i}$ data are included in Table 2 . It is interesting to see that cat $^{+}$with its new trianionic $\mathrm{L}^{3-}$ ligand is by far the best dinuclear WOC: it is roughly 100 times faster than $\mathbf{A}\left(\mathrm{H}_{2} \mathrm{O}\right){ }_{2}{ }^{3+}$ (compare entries 4 and 7 ) and about 18 times faster than $\mathbf{B}^{\prime}\left(\mathrm{H}_{2} \mathrm{O}\right)_{2}^{-}$(entry 5 ). This higher activity of cat $^{+}$correlates with the lowering of redox potentials for the corresponding aqua species. The same effect has been observed for mononuclear complexes, as can be seen from Table 2 when comparing entries 1-3: C(isoq) containing the carboxylate groups is about 570 times faster than $\left[\mathrm{Ru}(\operatorname{trpy})(\mathrm{bpy})\left(\mathrm{H}_{2} \mathrm{O}\right)\right]^{2+}$. Finally under identical conditions $\mathbf{C}$ (isoq) seems about 6 times faster than cat $^{+}$although in the absence of the anation effect they show essentially very similar activity. Because of the potentially bridging binding mode of the nitrate anion within the bimetallic pocket, the anation effects cat $^{+}$much more strongly than mononuclear $\mathbf{C}$ (isoq).

In conclusion, a rugged diruthenium complex cat $^{+}$based on a new pyrazolate ligand with appended carboxylate groups has been synthesized and fully characterized, including its spectroscopic signatures in several oxidation states. The trianionic character of the pyrazolate-bridged ligand scaffold imparts very low oxidation potentials, and the new system's catalytic performance in water oxidation is found superior to all previously known diruthenium catalysts and practically identical to the best mononuclear ones. This study shows how rational ligand design, founded on the knowledge gained in previous WOC research, leads to significantly improved catalysts; an $\begin{array}{llllll}\text { impressive } & \text { TOF } & \text { of } & 1.4 & \mathrm{~s}^{-1} & \text { was }\end{array}$

Table 2. Redox potentials and TOF's in $0.1 \mathrm{M}$ triflic acid $\mathrm{pH} 1$ aqueous solution, for cat $^{+}$and related mononuclear and dinuclear Ru complexes reported in the literature.

\begin{tabular}{|c|c|c|c|c|c|c|c|}
\hline \multirow{2}{*}{ Entry } & \multirow{2}{*}{ WOC } & \multicolumn{4}{|c|}{$E_{1 / 2}[\mathrm{~V}$ vs. SCE] } & \multirow{2}{*}{$\operatorname{TOF}_{i}^{a}\left[\mathrm{~s}^{-1}\right]$} & \multirow{2}{*}{ Ref } \\
\hline & & III,II / II,II & III,III / III,II & IV,III / III,III & IV,IV / IV,III & & \\
\hline 1 & {$\left[\mathrm{Ru}(\operatorname{trpy})(\mathrm{bpy})\left(\mathrm{H}_{2} \mathrm{O}\right)\right]^{2+}$} & 0.79 (III/II) & 0.98 (IV/III) & $1.55(\mathrm{~V} / \mathrm{IV})$ & --- & 0.015 & 21,22 \\
\hline 2 & $\mathrm{C}(\text { pic })_{2}$ & $0.36(I I I / I I)^{b}$ & $0.83(\mathrm{IV} / \mathrm{III})^{\mathrm{b}}$ & $1.01(\mathrm{~V} / \mathrm{IV})^{\mathrm{b}}$ & --- & $2.8\left(32.0^{c}\right)$ & this work (10) \\
\hline 3 & $\mathrm{C}(\text { isoq })_{2}$ & $0.39(\mathrm{III} / \mathrm{II})$ & 0.85 (IV/III) & $1.03(\mathrm{~V} / \mathrm{IV})^{d}$ & --- & $8.6\left(303^{c}\right)$ & this work (10) \\
\hline 4 & $\mathrm{~A}\left(\mathrm{H}_{2} \mathrm{O}\right)_{2}{ }^{3+}$ & 0.58 & 0.64 & 0.87 & 1.09 & 0.013 & $5,7 a, 23$ \\
\hline 5 & $\mathrm{~B}^{\prime}\left(\mathrm{H}_{2} \mathrm{O}\right)_{2}^{-}$ & 0.56 & 0.86 & 0.93 & 1.06 & 0.068 & 8 \\
\hline 6 & $\mathrm{D}(\mu-\mathrm{Cl})^{+}$ & $\sim 0.56^{\mathrm{d}}$ & $\sim 1.01^{\mathrm{d}}$ & --- & -- & $--\left(1.2^{\mathrm{e}}\right)$ & (9) \\
\hline 7 & cat $^{+}$ & 0.37 & 0.48 & 0.94 & 1.07 & $1.4\left(7^{f}\right)$ & this work \\
\hline 8 & OEC-PSII & --- & --- & --- & --- & $--(\sim 300)$ & (7) \\
\hline
\end{tabular}

${ }^{a}[$ cat $]=0.1 \mathrm{mM},\left[\mathrm{Ce}^{\mathrm{IV}}\right]=10 \mathrm{mM}\left([\mathrm{cat}]:\left[\mathrm{Ce}^{\mathrm{IV}}\right]=1: 100\right)$ in $0.1 \mathrm{M}$ triflic acid aqueous solution; total volume $2 \mathrm{~mL} ;{ }^{b}$ acetone/aqueous triflic acid solution (pH = 1.0$)(\mathrm{v}: \mathrm{v}$ $=1: 3)$

${ }^{\mathrm{c}}$ [cat $]=0.216 \mathrm{mM},\left[\mathrm{Ce}^{\mathrm{IV}}\right]=0.484 \mathrm{M}\left([\mathrm{cat}]:\left[\mathrm{Ce}^{\mathrm{IV}}\right]=1: 2240\right)$ in $0.1 \mathrm{M}$ triflic acid aqueous solution; total volume $3.7 \mathrm{~mL} ;{ }^{\mathrm{d}} 0.1 \mathrm{M} \mathrm{HNO} ;$ [cat $]=0.5 \mathrm{mM},\left[\mathrm{Ce}{ }^{\mathrm{IV}}\right]=20$ $\mathrm{mM}$ ([cat]: $\left.\left[\mathrm{Ce}^{\mathrm{IV}}\right]=1: 40000\right)$ in $0.1 \mathrm{M}$ triflic acid aqueous solution; total volume $20 \mathrm{~mL} ;{ }^{\mathrm{f}}$ obtained electrochemically

determined for cat $^{+}$using CAN as terminal oxidant, which is an improvement by more than two orders of magnitude compared to the original pyrazolate-based system $\mathrm{A}\left(\mathrm{H}_{2} \mathrm{O}\right)_{2}{ }^{3+}{ }^{[7]}$
Understanding the effect of the ligand framework on the catalytic performance is important, and bimetallic systems preorganized for O-O bond formation hold much promise for the development of heterogeneous catalysts with immobilized molecule-based 
active sites. Detailed mechanistic studies towards unravelling the actual O-O bond formation mechanism in cat $^{+}$as well as further elaboration of the growing family of pyrazolate-based WOCs, including their anchoring on conductive supports, are currently being pursued in our laboratories.

\section{Acknowledgements}

Support from the German Research Foundation (DFG project Me 1313/9-1) in the framework of the ERA Chemistry program and from MINECO (EUI2009-04139, CTQ-2013-49075-R and SEV-2013-0319) is gratefully acknowledged

Keywords: Water oxidation catalysis $\cdot$ artificial photosynthesis • ruthenium $\bullet$ binuclear complexes $\bullet$ oxygen evolving complex

[1] L. E. Doman, V. Arora, International Energy Outlook 2013 - Highlights, U.S. Energy Information Administration - Independent Statistics And Analysis, Washington, 2013, p. 1.

[2] (a) N. D. McDanie, S. Bernhard, Dalton Trans. 2010, 39, 10021-10030; (b) N. S. Lewis, D. G. Nocera, PNAS 2006, 103, 15729-15735.

[3] A. Llobet, F. Meyer, Angew. Chem. Int. Ed. 2011, A30-A33.

[4] (a) A. E. Clark, J. K. Hurst, Progr. Inorg. Chem. 2012, 57, 1-54; (b) A. Llobet, X. Sala, L. Escriche, RSC Energy and Environment Series 2012, 5, 273-287; (c) S. Romain, L. Vigara, A. Llobet, Acc. Chem. Res. 2009, 42, 1944-1953; (d) J. J. Concepcion, J. W. Jurss, M. K. Brennaman, P. G. Hoertz, A. O. T. Patrocinio, N. Y. Murakami Iha, J. L. Templeton, T. J. Meyer, Acc. Chem. Res. 2009, 42, 1954-1965.

[5] I. Romero, M. Rodríguez, C. Sens, J. Mola, M. R. Kollipara, L. Francàs, E. Mas-Marza, L. Escriche , A. Llobet, Inorg. Chem. 2008, 47, 1824 1834.

[6] S. W. Gersten, G. J. Samuels T. J. Meyer, J. Am. Chem. Soc. 1982 104, 4029-4030.

[7] (a) C. Sens, I. Romero, M. Rodríguez, A. Llobet, T. Parella, J. BenetBuchholz, J. Am. Chem. Soc. 2004, 126, 7798-7799.; (b) J. GarciaAnton, R. Bofill, L. Escriche, A. Llobet, X. Sala, Eur. J. Inorg. Chem. 2012, 4775-4789.

[8] S. Neudeck, S. Maji, I. López, S. Meyer, F. Meyer, A. Llobet, J. Am. Chem. Soc. 2014, 136, 24-27.

[9] Y. Xu, A. Fischer, L. Duan, L. Tong, E. Gebrielsson, B. Åkermark, L. Sun, Angew. Chem. 2010, 122, 9118-9121; Angew. Chem. Int. Ed. 2010, 49, $8934-8937$.

[10] L. Duan, F. Bozoglian, S. Mandal, B. Stewart, T. Privalov, A. Llobet, L. Sun, Nature Chem. 2012, 4, 418-423.

[11] G. C. Dismukes, R. Brimblecombe, G. A. N. Felton, R. S. Pryadun, J. W. Sheats, L. Spiccia, G. F. Swiegers, Acc. Chem. Res. 2009, 42, 19351943.

[12] H. Lv, J. Song, Y. V. Geletii, J. W. Vickers, J. M. Sumliner, D. G. Musaev, P. Kögerler, P. F. Zhuk, J. Bacsa, G. Zhu, C. L. Hill, J. Am. Chem. Soc. 2014, 136, 9268-9271.

[13] (a) L. Wang, L. Duan, Y. Wang, M. S. G. Ahlquist, L. Sun, Chem. Commun., 2014, 50, 12947-12950. (b) C. J. Richmond, R. Matheu, A. Poater, L. Falivene, J. Benet-Buchholz, X. Sala, L. Cavallo, A. Llobet, Chem. Eur. J. 2014, in press.

[14] (a) Y. Jiang, F. Li, B. Zhang, X. Li, X. Wang, F. Huang, L. Sun, Angew. Chem. 2013, 125, 3482-3485; Angew. Chem. Int. Ed. 2013, 52, 33983401.

[15] (a) J. I. van der Vlugt, S. Demeshko, S. Dechert, F. Meyer, Inorg. Chem. 2008, 47, 1576-1585; (b) B. Schneider, S. Demeshko, S. Dechert, F Meyer, Angew. Chem. 2010, 122, 9461-9464; Angew. Chem. Int. Ed.
2010, 49, 9274-9277; (c) B. Schneider, S. Demeshko, S. Neudeck, S. Dechert, F. Meyer, Inorg. Chem. 2013, 52, 13230-13237.

[16] S. V. Kryatov, E. V. Rybak-Akimova, F. Meyer, H. Pritzkow, Eur. J. Inorg. Chem. 2003, 1581-1590.

[17] F. Meyer, P. Rutsch, Chem. Commun. 1998, 1037-1038.

[18] all redox potentials reported in this work are against the SCE reference electrode

[19] N. Planas, T. Ona, L. Vaquer, P. Miro, J. Benet-Buchholz, L. Gagliardi, C. J. Cramer, A. Llobet, Phys. Chem. Chem. Phys. 2011, 13, 1948019484.

[20] C. Costentin, S. Drouet, M. Robert, J.-M. Saveant, J. Am. Chem. Soc. 2012, 134, 11235-11242.

[21] E. S. Rountree, B. D. McCarthy, T. T. Eisenhart, J. L. Dempsey Inorg. Chem. 2014, 53, 9983-10002.

[22] D. J. Wasylenko, C. Ganesamoorthy, M. A. Henderson, B. D. Koivisto, H. D. Osthoff, C. P. Berlinguette, J. Am. Chem. Soc. 2010, 132, 1609416106.

[23] S. Maji, I. López, F. Bozoglian, J. Benet-Buchholz, A. Llobet, Inorg. Chem. 2013, 52, 3591-3593.

[24] F. Bozoglian, S. Romain, M. Z. Ertem, T. K. Todorova, C. Sens, J. Mola, M. Rodríguez, I. Romero, J. Benet-Buchholz, X. Fontrodona, C. J. Cramer, L. Gagliardi, A. Llobet, J. Am. Chem. Soc. 2009, 131, 1517615187. 


\section{Entry for the Table of Contents}

\section{COMMUNICATION}

A new binuclear ruthenium water oxidation catalyst is presented that combines multiple beneficial structural elements for lowering the metal ions' redox potentials, enhancing catalyst durability and favoring the catalytic process. This leads to an impressive TOF of $1.4 \mathrm{~s}^{-1}$ in $\mathrm{Ce}^{\mathrm{IV}}$-mediated water oxidation and high electrocatalytic activity $\left(k_{\text {cat }}=7 \pm\right.$ $\left.4 \mathrm{~s}^{-1}\right)$. Spectroscopic and electrochemical signatures reflect the well-designed molecular properties.

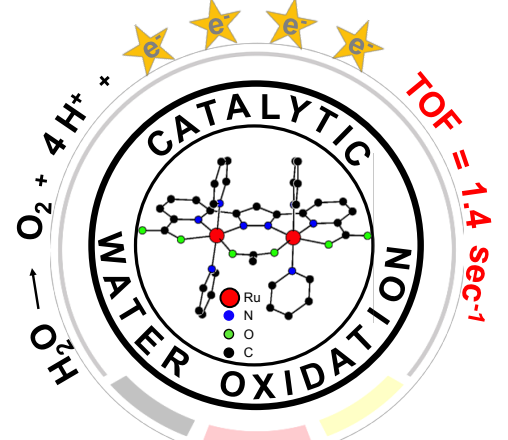

Anett C. Sander ${ }^{[a]}$, Somnath Maji ${ }^{[b]}$, Laia Francàs $^{[b]}$, Torben Böhnisch ${ }^{[a]}$,

Sebastian Dechert ${ }^{[a]}$, Antoni Llobet, ${ }^{[b] *}$ Franc Meyer ${ }^{[a] *}$

Page No. - Page No.

\section{A Highly Efficient Binuclear Ruthenium Catalyst for Water Oxidation}

